\title{
Margaret's Garden Shoppe: A Realistic Simulation Of Accounting For Small Entities
}

Andrew D. Schiff, Towson University

Margaret C. Smith, Chatman-Smith Consulting

\begin{abstract}
According to the American Institute of CPAs, over 58\% of new accounting graduates hired by CPA firms join those with fewer than 50 professional staff members, and over 38\% join CPA firms with fewer than 10 professional staff members [AICPA, 2005]. Many of these regional and local firms provide accounting services to small business clients, whose accounting needs can differ significantly from those of larger organizations that are the primary focus of most textbooks. Exposure to the unique requirements of smaller businesses can improve the ability of new staff accountants to serve these entities accurately and efficiently, thereby reducing budget overruns and client complaints. This case study, which is based on 15 years of accounting and consulting experience, provides a unique experience in that it emphasizes the source documents, transactions and unique accounting needs of small businesses. It has been classroom-tested for accuracy and ease of use, and is suitable for principles, systems and first intermediate courses in accounting.
\end{abstract}

\section{INTRODUCTION}

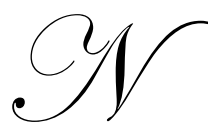

early all accounting principles textbooks contain examples and assignments which introduce students to the accounting cycle and to the various accounting subsystems. In addition, there are separate practice sets such as the Systems Understanding Aid [Arens and Ward, 2001) and others [Buckless, et. al, 2005; Mansuetti and Weidkamp, 2001] that accomplish the same objectives, and which often incorporate separate source documents, accounting journals and ledgers. Most of these examples and practice sets simplify the business setting in order to cover the underlying concepts and procedures with a minimum of distractions. When additional source documents and transactions are added, they often reflect what would be found in mid-size and larger organizations with reasonably complex transaction processing procedures. For example, the additional source documents may consist of bills of lading, return merchandise authorizations, debit and credit memoranda, etc. The additional transactions might involve events such as investments in securities, intercompany loans, unearned income, gains and losses, etc.

The above approach is effective for students who will become staff accountants and auditors for larger organizations with many customers, vendors, and other business partners. However, it does not fully prepare students for the unique transactions and procedures they will need to master in order to provide accounting services for startup entities and small businesses. While the source documents generated by small businesses and the techniques required to efficiently prepare their financial statements are similar to those found in larger organizations, small businesses have their own specific requirements and constraints [Bostrom, 2005; Mucha-Aydlott, 2005; National Society of Public Accountants, 1992]. As stated by the NSPA [1992], "there are major differences between small and big businesses in addition to size. Small businesses have their own problems, needs and peculiarities which must be handled and solved in ways distinctly applicable to them" [iii].

Although many accounting students may aspire to begin their careers in international public accounting firms or multinational corporations, over 58\% of new accounting graduates hired by CPA firms join those with fewer than 50 professional staff members, and over 38\% join CPA firms with fewer than 10 professional staff 
members [AICPA, 2005]. Since smaller firms are more likely to provide accounting services to small businesses, exposure to the unique requirements of such entities will reduce the likelihood of errors, inefficiencies, cost overruns and unhappy clients. Moreover, even students who begin their careers in larger firms may occasionally be asked to assist with the accounting needs of smaller entities. Familiarity with the unique requirements of such entities will make these individuals more valuable to their employers.

In addition to new accounting graduates hired by CPA firms, nearly $20 \%$ are hired directly by businesses and nonprofit organizations, of which many are smaller in size [AICPA, 2005]. Furthermore, there is substantial evidence that realistic job previews help individuals select careers with which they are more likely to be satisfied [Phillips, 1998; Suszko and Breaugh, 1986]. A realistic preview of small business accounting can expose students to a career path within the profession which they might not otherwise have considered, and which might lead to greater fulfillment than working primarily with or for large organizations.

As noted by Krause [2005a], "the central problem that a case writer faces is securing real-life data" [64]. This problem was minimized for the current project because the authors have nearly 15 years of experience providing accounting and consulting services directly to small businesses. As a result, it was possible to draw upon a wide range of actual engagements to develop the business environment and transactions which comprise this project. These first-hand experiences were supplemented by a detailed review of the professional literature for additional insights into the accounting needs of small organizations, and the procedures followed to respond to them [Bostrom, 2005; Copeland, 2004; National Society of Public Accountants, 1992; Plank and Plank, 1994].

Upon completion, the case was extensively classroom-tested among students of all levels of ability and educational attainment, ranging from those with no prior accounting background through those with significant work experience. A number of refinements were then made based upon the feedback and suggestions received. Subsequent follow-up with these students indicates that this case is particularly effective in preparing individuals for entry-level staff positions in public accounting firms serving small to mid-size organizations, employment in such organizations, and for supervising accounting paraprofessionals.

\section{DISTINCTIVE FEATURES}

This case provides a unique learning experience in several respects. First, the source documents which are commonly generated by small businesses are stressed, such as register tapes, check stubs, individual credit / debit card receipts, and others. Also, the transactions recorded on these documents and others are with consumers and business partners reflective of those with whom a small organization would typically come in contact.

Second, the authors have found that inexperienced small business accountants usually are not sensitive to the limited resources available to small business owners to address accounting issues. As a result, they can create accounting systems which are too elaborate or time-consuming for the client to maintain. A prime example of when this can occur involves inventory. We have encountered various instances in which entry-level staff accountants created complex computerized perpetual inventory systems which were subsequently never used by the client.

Therefore, four different inventory accounts were created to illustrate four approaches to accounting for inventory which can be chosen based upon the requirements and constraints of the small business entity. In addition, students are given a chance to select what they consider to be the most effective and efficient approach to accounting for each of the four categories of inventory in the case. This creates an opportunity for slightly different outcomes and a discussion of the benefits and limitations of each, which characterizes a "classic" case [Krause, 2005b].

Third, the month-end adjusting entries are restricted to those which the student is likely to encounter in a small business, which would include the computations of cost of goods sold discussed above, credit card fees, payroll taxes, etc. This will help familiarize students with the adjusting entries that they will be required to prepare for certain clients. Fourth, the accounting system is set up to accommodate certain more sophisticated small business issues, such as accrual-basis financial statements combined with a cash-basis tax return, and the need to remove nonbusiness transactions from the accounting records. 
Finally, the case has several practical advantages. In classroom testing, it took an average of only four to six hours to complete, and thus did not require the elimination of another assignment or project. Also, the complete case is available in electronic form from the authors which minimizes the cost to students [Kinzie, 2006]. Further, for instructors who want to prepare students to use computerized accounting software, each of the blank journals contains references to the appropriate window(s) for entering the related transactions in two popular small business accounting software packages (QuickBooks and Peachtree).

\section{THE CASE: MARGARET'S GARDEN SHOPPE}

\section{INTRODUCTION}

Clarissa Rainess had recently joined Pratt and Bosley, LLC, a regional accounting firm serving individuals, small and midsize businesses. In addition to tax preparation and planning for individuals, Pratt and Bosley has a number of small business clients for which it provides tax, accounting and consulting services. Clarissa is meeting with Bill Haskins, a manager at the firm, to discuss a new client.

“The client's name," said Haskins, "is Margaret's Garden Shoppe, and they’ve just completed their first month in business, and they seem to be a well-managed company. They want us to maintain their accounting records, and to prepare their quarterly payroll and year-end tax returns. I've taken some detailed notes about the client for you to review, and I'd like you to prepare this month's financial statements."

Clarissa was excited about her new assignment, but a little nervous as well. It was one thing, she thought, to study the accounting cycle in a textbook and quite another to process the transactions for an actual business. As she looked at the documents provided by the client, she realized that while some looked familiar, there were others with which she had no previous experience. Also, she suspected that the accounting techniques used in the small business world might differ in certain respects from those used in the Fortune 1000 corporations which were the focus of most of her textbooks.

"One more thing," Bill Haskins said. "I'd like you to prepare the financial statements for Margaret's Garden Shoppe by hand before we do it on the computer. There are a couple of reasons for this. First, we've found that many of our new staff accountants need to strengthen their knowledge of the accounting cycle. We've learned that the most effective way to solve this problem is to have each new staff accountant prepare the financial statements for a one of our small business clients on a manual basis at least once. It should only take you a few hours, and it will give you a chance to fill in any gaps in your knowledge.

“Also," Bill continued, "when you start using accounting software for this client you'll make fewer mistakes. That will save you a lot of frustration, because mistakes made with accounting software can be very difficult to straighten out. Plus, you'll be a much better auditor if you have a thorough knowledge of the accounting cycle. So review my notes, get started on their financial statements, and let me know if you have any questions."

Clarissa opened the client file for Margaret's Garden Shoppe, and began her new assignment.

\section{COMPANY OVERVIEW}

Margaret's Garden Shoppe (MGS) is a specialty retailer in Maryland which caters to the residential and small business communities. It was organized as a limited liability company with one owner. The major source of revenue for MGS comes from the sale of flowers, shrubs and lawn care products, including mulch, topsoil, and other items. MGS also has several commercial clients for whom it provides lawn care services, including landscaping and routine maintenance. In addition, MGS operates a café during business hours, serving taxable and non-taxable food items. 


\section{ACCOUNTING SYSTEM}

MGS uses the accrual basis of accounting. A chart of accounts for a merchandising organization, as well as the standard accounting journals and subsidiary ledgers, will be adequate to meet the client's needs.

In addition to the usual customer invoices and vendor bills, there are source documents which are not generated by other clients, especially our larger ones. These include Z-tapes, which report the total sales and cash receipts from the cash register for one or more days; credit card receipts, which are used by MGS to make all types of purchases; and debit card slips, which are also used for purchases. All other cash receipts and disbursements will be recorded from deposit slips and check stubs. MGS prepares their own payroll, so some of these stubs will be for pay checks. However, we will prepare the adjusting journal entries for employer payroll taxes.

Typical examples of a Z-tape, credit card receipt and debit card slip are shown in Figures 1 through 3. The Z-tapes will be recorded in the cash receipts journal, the credit card receipts in the purchases journal, and the debit card slips in the cash disbursements journal.

Figure 1: Margaret's Garden Shoppe Example of $Z$ Tape

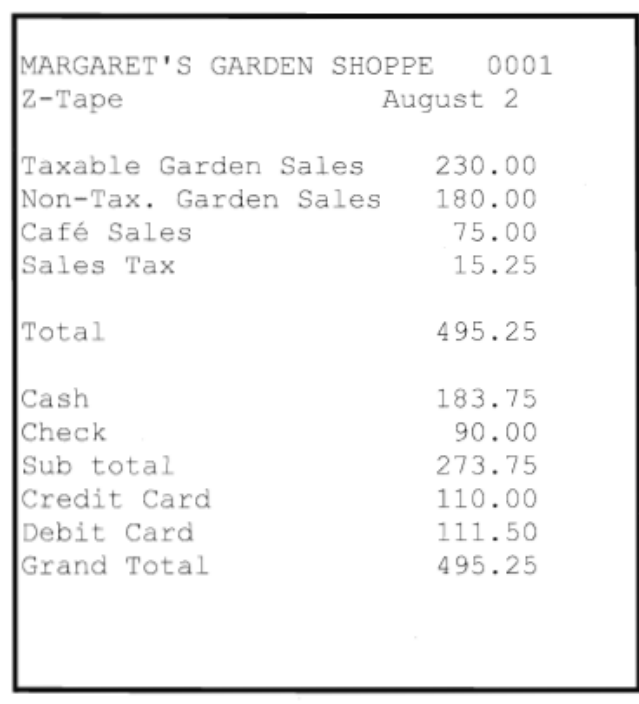

Figure 2: Margaret's Garden Shoppe Example of Credit Card Receipt

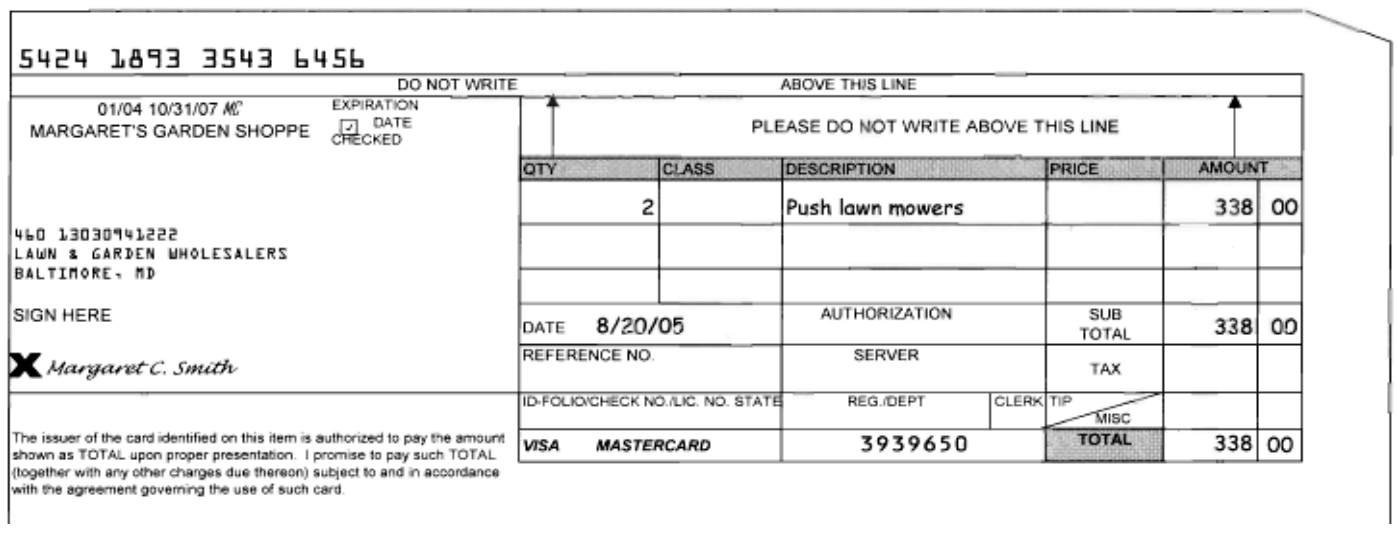


Figure 3: Margaret's Garden Shoppe

Example of Debit Card Receipt

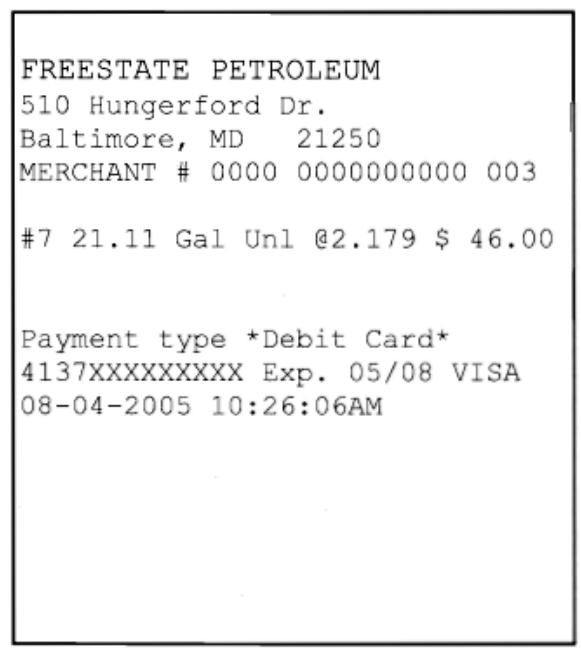

\section{INVENTORY}

MGS groups its inventory into four categories, each of which is shown in its own asset account. These categories are (1) flowers and shrubs, (2) garden supplies and mulch, (3) topsoil, and (4) food for the café. Because the flowers and shrubs are expensive and highly perishable, MGS wants to keep a precise record of the quantity and amount which should be in inventory to facilitate reordering and the calculation of inventory shortages and losses. For each of the flowers and shrubs sold, MGS copies the cost of each item, obtained from the vendor's price list, onto the customer invoice. The cost is written in reverse order in the description box of the store copy of the invoice. For example, a cost of $\$ 25.00$ per unit is written as (0052).

For the other three inventory categories, MGS visually inspects the quantities on hand every few days to decide what should be reordered. Because the topsoil is competitively priced, each shipment usually sells out within a few days after it arrives. MGS does not feel that the cost of maintaining detailed accounting records of the individual items in these other three categories is justified. However, they are willing to take an inventory at the end of each month of the garden supplies and mulch, and the topsoil.

MGS is not willing to take a monthly inventory of the food in the café, since they feel that it is too time-consuming to count many small, inexpensive items. After comparing the selling prices to the costs for a sample of café items, we determined that the gross profit on café sales averages about $60 \%$.

It will be necessary to choose from the perpetual, periodic and gross profit methods to compute cost of goods sold for each of the above four inventory categories. Keep in mind that in addition to the standard formula for the periodic method, an alternative is to debit cost of goods sold immediately for all purchases and to adjust this figure for the net change in inventory during the period. For each inventory category, the method which provides the level of detail required by the client in the least amount of time should be used. A level of detail beyond the client's requirements does not add value.

\section{VENDORS}

MGS purchases flowers, shrubs, garden supplies and topsoil from three vendors, all of whom offer terms of 2/10, Net 30. Food inventory for the café is purchased from various other vendors. In addition, MGS offers subcontracted lawn maintenance and landscaping services. No purchase discounts are offered by the latter trading partners. In accordance with state law, no sales tax is paid on services or on inventory purchased for resale. 
Purchases made using the company's Wachovia Bank Master Card will be credited to a separate current liability account instead of accounts payable. This is because the IRS allows credit card purchases to be treated as cash purchases, so they will not have to be removed from the accounting records if we choose to prepare the tax return on the cash basis.

\section{CUSTOMERS}

Most sales are for cash, and are recorded in an electronic cash register. Every two or three days, totals are computed and are printed on a Z-tape receipt. The Z-tape shows total sales by account, sales tax payable, and the forms of payment received. No sales tax is charged on sales of services, nor on sales of products to resellers or nontaxable entities.

Sales of flowers and shrubs, however, are recorded on individual invoices. This enables MGS to maintain a perpetual inventory of each item, which cannot currently be accomplished with the information recorded in the cash register. As mentioned above, the unit cost of each flower or shrub is written in reverse next to its description on the store copy of the invoice. Sales discounts offered are either Net 30 or 2/10, Net 30.

\section{EMPLOYEES}

Payroll is computed bi-weekly. In accordance with state law, overtime is paid to hourly employees at 1.5 times their regular pay rate for all hours worked in excess of 40 per week. MGS employs three people, whose background information is shown below.

\begin{tabular}{|c|c|c|c|}
\hline Name & Title & Type & $\begin{array}{c}\text { Filing Status } \\
\text { No. of Exempt. }\end{array}$ \\
\hline Christopher Armstead & Café Manager & Full-time & Married \\
& & Salaried & 3 exemptions \\
\hline Francis Stuart & Cashier & Part-time & Single \\
& & Hourly exemptions \\
\hline Mary Holmes & Garden Shop Manager & Full-time & Single \\
& & Hourly & 1 exemption \\
\hline
\end{tabular}

Federal, Social Security, Medicare, state, and local taxes are withheld from each employee's paycheck. The employer's matching contribution for Social Security and Medicare will be recorded as an adjusting entry. Since MGS prepares its own payroll, it will be recorded into the payroll journal "after the fact" from the payroll check stubs. The owner did not take any draws in this, her first month of business.

\section{ADJUSTING JOURNAL ENTRIES}

We anticipate about ten monthly adjusting journal entries. The first is for employer payroll taxes, which consist of the employer's matching contribution for Social Security and Medicare, state unemployment taxes (SUTA) at $3.0 \%$ of the first $\$ 8,500$ of gross pay, and federal unemployment taxes (FUTA) at $0.8 \%$ of the first $\$ 7,000$ of gross pay.

The next is depreciation expense, which we will calculate for financial statement purposes using the straight-line method based on the useful life of each type of asset (five years for the equipment and vehicles, and seven years for the furniture). An accelerated method allowed under MACRS will be used for the client's tax return.

Other adjustments include expensing prepaid insurance, for which the annual premium of $\$ 1,200$ was paid in advance. Bank service charges and interest will be obtained from the bank statement, and credit card fees will be obtained by comparing the amounts of credit card sales to the deposits wire-transferred into the account. 
Finally, it will be necessary to compute cost of goods sold for each of the four inventory accounts. If the perpetual method of inventory is used for the account, this will have been done at the time of sale. If the periodic method is used, an adjustment will be required which incorporates the net change in inventory during the month. This information will be provided by the client. If the gross profit method is used, the computation will be based on the cost complement percent multiplied by café sales for the month. Additional details are included in my Inventory notes above.

\section{TEACHING NOTE}

This case was presented to students who had received instruction in the accounting cycle, normally in a principles of accounting or similar course. Before beginning the case, students were advised that representative samples of various source documents were included in the case, and that all source documents, journals, subsidiary ledgers and other accounting documents were contained in a separate handout or on a compact disk. (They could also be loaded onto a course Web site.)

It was found that students had greater success in completing the case if several features of it were discussed at the beginning of the assignment. To begin with, first it is helpful to demonstrate how one or more of each source document would be recorded into the corresponding journal. This is particularly true for the less standard source documents, such as the register tapes and the credit and debit card receipts. It should be emphasized that, as a practical matter, the business owner must provide enough information on each source document to establish what accounts will be debited and credited.

MGS groups its inventory into four categories, each of which is shown in its own asset account. For each one, it is necessary for the student to choose from the perpetual, periodic and gross profit methods to compute cost of goods sold. Detailed cost information is readily available for only one of these four categories, and the client refuses to count the inventory in another category on a regular basis. For each inventory account, the student should select the method which provides the level of detail required by the client in the least amount of time.

Constraints such as the above are frequently encountered when providing accounting services to small businesses, and this provides an opportunity to discuss the benefits and limitations associated with each method of accounting for inventory and cost of goods sold. Doing so will help prepare students to choose methods which meet the needs of clients for accuracy and control, but which are efficient and cost-effective as well.

Based on the information presented in the case, the perpetual method should be used for the flowers and shrubs. Columns to record the credit to inventory and the debit to cost of goods sold exist in the sales journal. Although an inventory subsidiary ledger has been omitted to save time, the professor may ask students to prepare one. (It is also helpful to state that while MGS currently obtains the cost from the vendor's price list, a computerized accounting system could retrieve this data directly from the inventory subsidiary ledger.) For the food inventory, the gross profit method is the only feasible approach based upon the figures that the client is willing to provide. The credit to inventory and the debit to cost for the cost complement of café sales (40\%) is an adjusting journal entry.

The periodic method should be used for the two remaining inventory asset accounts because the client is willing to take an inventory of each at the end of each month, and because they do not feel that the cost of maintaining records of the individual items in these accounts is justified. Even if the cost complements could be determined for the two remaining inventory accounts from the facts in the case, the periodic method should be used because it is more accurate. The beginning inventory amounts are included in the general journal entry to record the opening balances, and the ending inventory amounts are provided with information for the month-end adjusting journal entries. Purchases of the garden supplies and mulch are debited to inventory, although a purchases account could also be used. Purchases of topsoil, because of its rapid turnover, are debited directly to cost of goods sold which is then adjusted for the net increase or decrease in inventory during the period. The second approach introduces students to a practice that is frequently used for small business financial statement and tax return preparation. 
Figure 4: Margaret's Garden Shoppe, General Journal

\begin{tabular}{|c|c|c|c|c|c|c|}
\hline Date & Num & P.R. & $\begin{array}{l}\text { Acct. } \\
\text { Nbr }\end{array}$ & Description & Debit & Credit \\
\hline \multirow[t]{10}{*}{$8 / 1 / 2005$} & 1 & $\sqrt{ }$ & 100 & Checking & $5,000.00$ & \\
\hline & & $\sqrt{ }$ & 130 & Inventory - Flowers \& Shrubs & $2,850.00$ & \\
\hline & & $\sqrt{ }$ & 131 & Inventory - Garden \& Mulch & $4,100.00$ & \\
\hline & & $\sqrt{ }$ & 132 & Inventory - Top Soil & 250.00 & \\
\hline & & $\sqrt{ }$ & 134 & Inventory - Food & $1,100.00$ & \\
\hline & & $\sqrt{ }$ & 140 & Prepaid Insurance & $1,200.00$ & \\
\hline & & $\sqrt{ }$ & 150 & Equipment & $9,000.00$ & \\
\hline & & $\sqrt{ }$ & 160 & Furniture & $1,500.00$ & \\
\hline & & $\sqrt{ }$ & 170 & Vehicle & $6,000.00$ & \\
\hline & & $\sqrt{ }$ & 305 & Opening Balance Equity & & $31,000.00$ \\
\hline \multirow[t]{5}{*}{$8 / 15 / 2005$} & 2 & & 610 & Employer Payroll Tax Expense & & \\
\hline & & & 251 & Payroll Liabilities - Medicare & & \\
\hline & & & 252 & Payroll Liabilities - Social Security & & \\
\hline & & & 255 & Payroll Liabilities - SUTA & & \\
\hline & & & 256 & Payroll Liabilities - FUTA & & \\
\hline \multirow[t]{5}{*}{$8 / 31 / 2005$} & 3 & & 610 & Employer Payroll Tax Expense & & \\
\hline & & & 251 & Payroll Liabilities - Medicare & & \\
\hline & & & 252 & Payroll Liabilities - Social Security & & \\
\hline & & & 255 & Payroll Liabilities - SUTA & & \\
\hline & & & 256 & Payroll Liabilities - FUTA & & \\
\hline \multirow[t]{4}{*}{$8 / 31 / 2005$} & 4 & & 608 & Depreciation Expense & & \\
\hline & & & 151 & Equipment - Accumulated Depreciation (5 yrs) & & \\
\hline & & & 161 & Furniture - Accumulated Depreciation (7 yrs) & & \\
\hline & & & 180 & Vehicle - Accumulated Depreciation (5 yrs) & & \\
\hline \multirow[t]{2}{*}{$8 / 31 / 2005$} & 5 & & 613 & Insurance Expense & & \\
\hline & & & 140 & Prepaid Insurance & & \\
\hline \multirow[t]{4}{*}{$8 / 31 / 2005$} & 6 & $\sqrt{ }$ & 603 & Bank Service Charges & 15.00 & \\
\hline & & $\sqrt{ }$ & 450 & Interest Income & & 2.10 \\
\hline & & $\sqrt{ }$ & 100 & Checking & & 12.90 \\
\hline & & & & Per Bank Statement & & \\
\hline \multirow[t]{3}{*}{$8 / 31 / 2005$} & 7 & $\sqrt{ }$ & 606 & Credit Card Fees & 72.50 & \\
\hline & & $\sqrt{ }$ & 100 & Checking & & 72.50 \\
\hline & & & & Per Bank Statement & & \\
\hline \multirow[t]{3}{*}{$8 / 31 / 2005$} & 8 & & 531 & Cost of Goods Sold - Garden \& Mulch & & \\
\hline & & & 131 & Inventory - Garden \& Mulch & & \\
\hline & & & & Starting + purchases - ending of 1410.00 & & \\
\hline \multirow[t]{3}{*}{$8 / 31 / 2005$} & 9 & & 532 & Cost of Goods Sold - Top soil & & \\
\hline & & & 132 & Inventory - Top soil & & \\
\hline & & & & Starting - Ending of $175=$ Adjustment & & \\
\hline \multirow[t]{3}{*}{$8 / 31 / 2005$} & 10 & & 534 & Cost of Goods Sold - Food & & \\
\hline & & & 134 & Inventory - Food & & \\
\hline & & & & Café Sales * .40 & & \\
\hline TOTAL & & & & & & \\
\hline
\end{tabular}


The necessary remaining information to record the adjusting journal entries is included in the case and in the general journal, a copy of which is shown in Figure 4. To help organize this step for students, the required journal entries have been set up and several basic ones have been completed. However, the professor may choose to make this step more challenging by requiring students to produce the general journal from scratch, while providing the amount information appearing in Figure 4 on a separate document, in class, or on a course Web site.

The cost of the fixed assets to be depreciated, and the prepaid insurance to be written off, are included in the general journal entry to record the opening balances for MGS. The percentages for SUTA and FUTA are contained in the case. Students should be reminded that no employee has reached the cutoff for SUTA, FUTA or Social Security because this is the company's first month in business. (It is also useful to mention that in a computerized accounting system, employer payroll taxes are often calculated and recorded automatically in conjunction with payroll processing.) The amounts for the other adjusting entries, including the ending inventory for garden supplies and mulch, and the ending inventory for topsoil are shown with the related entries in the general journal.

The complete source documents and the blank journals, ledgers and other accounting records, along with the solution to the case, are available from the first author (at no charge) in either hard copy or portable document file (.pdf) format. The latter offers the convenience of being uploadable to a course Web site. This additional material also includes a summary of the steps involved in completing the accounting cycle, which may be a useful reminder for some students. And, as noted above, each of the blank journals contains references for entering the related transactions in two popular small business accounting software packages, to facilitate the transition to computerized accounting software.

\section{REFERENCES}

1. AICPA. The Supply of Accounting Graduates and the Demand for Public Accounting Recruits. New York, NY: American Institute of Certified Public Accountants, 2005.

2. Arens, A. and Ward, D. Systems Understanding Aid, $5^{\text {th }}$ Edition. Okemos, MI: Armond-Dalton Publishers, 2001.

3. Bostrom, A. Practical Small Business Applications. Salt Lake City, UT: Universal Accounting Systems, 2005a.

4. Bostrom, A. Advancing Your Accountability. Salt Lake City, UT: Universal Accounting Systems, 2005b.

5. Buckless, F., Ingraham, L. and Jenkins, A. Comprehensive Assurance and Systems Tool. Upper Saddle River, NJ: Pearson Education, 2005.

6. Copeland, T. Family Child Care 2004 Tax Workbook and Organizer, St. Paul, MN: Redleaf Press, 2004.

7. Kinzie, S. Swelling Textbook Costs Have College Students Saying Pass. The Washington Post, January $23^{\text {rd }}, 2006$, p. A01.

8. Krause, M. Bridging the Gap Between Professors and Practitioners. The CPA Journal, February 2005a, p. 64

9. Krause, M. Bridging the Gap Between Professors and Practitioners (Continued). The CPA Journal, November 2005b, p. 68

10. Mansuetti, L. and Weidkamp, K. Wheels Exquisite Practice Set, $2^{\text {nd }}$ Edition, New York: McGraw-Hill, 2001

11. Mucha-Aydlott, J. How to Open Your Own Accounting and Bookkeeping Service, $2^{\text {nd }}$ Edition. Lakeside, CA: San Diego Business Accounting Solutions, 2005.

12. National Society of Public Accountants. Portfolio of Accounting Systems for Small and Medium-Sized Businesses, $3^{\text {rd }}$ Edition. Englewood Cliffs, NJ: Prentice-Hall, 1992.

13. Phillips, J. Effects of Realistic Job Previews on Multiple Organizational Outcomes: A Meta-Analysis. Academy of Management Journal, Vol. 41, No. 6, 1998, pp. 673-690.

14. Plank, T, and Plank, R. Encyclopedia of Accounting Systems. Englewood Cliffs, NJ: Prentice-Hall, 1994.

15. Suszko, M. and Breaugh, J. The Effects of Realistic Job Previews on Applicant Self-Selection and Employee Turnover, Satisfaction, and Coping Ability. Journal of Management, Vol. 12, No. 4, 1986, pp. 513-523. 
Journal of Business Case Studies - March 2008 Volume 4, Number 3

NOTES 